\title{
Pobreza e problemas sociais no interior do Brasil da Primeira República: o caso de Alfenas-MG
}

\section{Poverty and social problems in the Brazilian hinterland during the first Republic: the case of Alfenas-MG}

\author{
Alisson Eugênio*
}

\begin{abstract}
Resumo
Esse texto é resultado de um estudo cujo objetivo é investigar alguns aspectos da pobreza na cidade de Alfenas. Para isso foram utilizados os requerimentos dos seus cidadãos, nos quais há diversas solicitações ao agente executivo municipal (termo utilizado para designar o cargo equivalente à função de prefeito) e à Câmara dos vereadores. Dessa documentação, foram retiradas as informações relativas à pobreza que serão utilizadas como indicadoras de desigualdades sociais em um dos mais prósperos municípios do Sul de Minas Gerais na época da Primeira República, para saber como as demandas dos pobres eram fundamentadas e, com isso, como elas podem contribuir para a compreensão dos problemas enfrentados pela população pobre na luta diária pela subsistência.
\end{abstract}

Palavras-chave: pobreza, requerimentos, problemas sociais.

\begin{abstract}
This text is the result of a study aiming to investigate some aspects of poverty in the city of Alfenas. For this, the demands of its citizens were used, in which there are several requests to the municipal executive agent (term used for the equivalent post at the mayor function) and the city council. This documentation was taken from information on the demands of the poor, to be used as indicators of social inequalities in one of the most prosperous cities in the South of Minas Gerais at the time of the First Republic, to learn how the demands were justified and, therefore, as they can contribute to the understanding of the problems faced by the poor in the daily struggle for survival.
\end{abstract}

Keywords: poverty, request, social problems.

* Doutor em História pela USP. Professor do curso de História da Universidade Federal de Alfena. E-mail: alissoneugenio@yahoo.com.br 
A pobreza é um fenômeno ou fato social (nos termos de Durkhein) antigo. Com níveis distintos de intensidade e de afetação do tecido social, ela é, normalmente, fruto da distribuição desigual da riqueza, principalmente em sociedades, marcadas por forte desequilíbrio social, em que o Estado pouco ou nada faz para compensar ou amenizar os seus efeitos, que por essa razão atingem proporções dramáticas. ${ }^{1}$

Durante o longo tempo da experiência humana, entre as primeiras formações sociais e os dias atuais, a pobreza foi percebida de diversas maneiras. No Ocidente, desde pelo menos o século XVI, quando as relações de produção capitalistas começaram a predominar, ela passou a ser vista como problema social, depois de ser percebida, de um modo geral, na época medieval, como uma virtude essencial para a salvação religiosa. ${ }^{2}$

Daí em diante, com a consolidação do capitalismo, o avanço da urbanização e a explosão demográfica, que dá sentido, no final do século XVIII, à tese pessimista de Malthus (a de um futuro sombrio, marcado pela fome e revoltas antifamélicas, para a humanidade, devido ao desequilíbrio entre o aumento da população e a oferta de alimentos), a pobreza, que ainda era concebida como uma fatalidade, ou como um destino, passa cada vez mais a ser concebida como resultado de causas sociais. Isso se deu à medida que as sociedades se laicizavam, com o desencantamento da vida, do mundo, do homem, do seu corpo e de suas relações. Assim, a aura sagrada que revestia a pobreza é removida e os indivíduos a ela submetidos começam a ser vistos, no contexto de uma ordem econômica fundamentada no liberalismo, como produto do seu próprio fracasso pessoal. ${ }^{3}$

No Brasil durante a Primeira República, a pobreza vicejava tanto quanto os cafezais que impulsionavam a riqueza nacional. A nova ordem política, inaugurada por um processo histórico iniciado com a crise do Império, foi oriunda de uma cisão da classe dominante. Uma nova aristocracia substituía outra no comando do poder, com o apoio dos militares, enquanto o povo,

\footnotetext{
${ }^{1}$ Essa afirmação foi elaborada com base em POSTONE, Moishe. Crítica, Estado e economia. In: RUSH, Fred (org.) Teoria crítica. Aparecida, Idéias e Letras, 2008, pp. 203-233. FERREIRA, Jorge e ALMEIDA, Lucíola de Delgado (orgs.). o Brasil republicano: o tempo do liberalismo excludente. Vol. 1, Rio de Janeiro, Civilização Brasileira, 2003. SAMIR, Almir. Desenvolvimento desigual: ensaio sobre as formações sociais do capitalismo periférico. São Paulo, Forense Universitária, 1976.

${ }^{2} \mathrm{O}$ processo histórico da transformação da visão sobre a pobreza e seus fundamentos estruturais foi estudado, entre outras pessoas, por DAVIS, Natalie Zemon. Culturas do povo: sociedade e cultura o início da França moderna. Rio de Janeiro, Paz e Terra, 1990, cap 2, pp. 23-61.

${ }^{3} \mathrm{~A}$ esse respeito, há uma síntese feita por VISCARDI, Cláudia Maria Ribeiro em Pobreza e assistência no Rio de Janeiro na Primeira República. História, Ciência, Saúde-Manguinhos, vol. 8, suplemento 1, 2011.
} 
segundo um cronista da época, assistia a tudo "bestializado". Tratava-se de uma transição pelo alto, sem participação das camadas populares, em um processo de modernização conservadora, isto é, de transformação na organização política sem mudanças na estrutura social. Afinal, o que estava em jogo era o interesse da nova elite econômica, a qual se empenhou na construção de um novo pacto político, conhecido como pacto oligárquico (sustentado na política do café com leite no nível federal, na política dos governadores no nível estadual e no coronelismo no nível municipal) para controlar a máquina do Estado e proteger seus interesses de classe. O Estado liberal originado desse pacto não contemplou a grande massa da população. Esta continuou entregue à sua própria sorte, ou ao que sobrou da sensibilidade religiosa, expressa na caridade pública, ou à dádiva dos protagonistas da situação política local, ancorada no paternalismo agora na sua manifestação coronelista. ${ }^{4}$

O resultado histórico disso não poderia ser diferente; a pobreza disseminou-se e assumiu contornos dramáticos, cujo caso mais emblemático é a experiência de Canudos, para onde migrou grande quantidade de pessoas pobres, empurrada pela seca, pelo descaso das autoridades públicas e pela violência imperante nos sertões. Atraídos pelas notícias de uma nova Canaã governada por um líder messiânico (Antônio conselheiro), os que para lá migraram acabaram vítimas de uma tragédia histórica proporcionada por um governo que os via como uma ameaça à ordem republicana.

Para se compreender tal resultado, é necessário relembrar como a pobreza era estruturalmente engendrada. A macroeconomia da Primeira República ainda estava estruturada nos moldes da economia colonial. o país era dependente, em larga medida, da monocultura cafeeira (afora outros produtos exportáveis, como a borracha, e da produção voltada para o abastecimento interno com sua dinâmica própria). Consequentemente, quase toda

\footnotetext{
${ }^{4}$ Um de nossos mais eminentes historiadores, já em 1936, HOLANDA, Sérgio Buarque de, em sua clássica obra Raízes do Brasil. São Paulo, Cia das Letras, 1997, afirmou na p. 160: "É curioso notar que os movimentos aparentemente reformadores, no Brasil, partiram quase sempre de cima para baixo". O entendimento da transição política acima referida é tomado de COSTA, Emília Viotti da. Da Monarquia à República: momentos. 3 ed.,São Paulo, Brasiliense, 1985 cap. 9. A expressão os bestializados foi proferida por um senador contemporâneo da proclamação da República, Aristides Lobo, e é usada por CARVALHO, José Murilo de, para dar título à sua obra Os bestializados: o Rio de Janeiro e a República que não foi. 3 ed., São Paulo, Cia das Letras, 1996. Já o conceito de modernização conservadora foi formulado por MOORE Jr., Barrington. Origens sociais da ditadura e da democracia. São Paulo, Martins Fontes, 1975, para explicar o modelo de transição política em países, como a Alemanha, onde a burguesia aliou-se com a aristocracia para promover a modernização. O coronelismo foi um fenômeno político, estudado por NUNES, Victor Leal. Coronelismo, enxada e voto. 3 ed., Rio de Janeiro, Nova Fronteira, 1997, resultante da "superposição de formas desenvolvidas do regime representativo a uma estrutura econômica e social inadequadas", na qual o poder público ainda era frágil demais para prescindir do poder privado dos potentados locais para se impor à população (p. 40).
} 
política econômica nacional girava em torno dela, cujo aumento exponencial das exportações (acrescido do ciclo da borracha voltado para o comércio exterior) acabou gerando maior interesse na produção de café, atraindo mais capitais estrangeiros (para investir na sua produção ou como resultado do crescimento do seu valor exportado). Isso criou em alguns momentos crises de superprodução e desequilíbrio no câmbio que impactaram negativamente a economia geral do país, provocando algumas distorções conjunturais com graves efeitos colaterais. Um deles foi a inflação. O preço artificialmente alto do café (garantido pela compra, desde 1906, pelos cofres públicos dos maiores produtores, SP e MG, dos excedentes não exportados) acabava arrastando consigo os preços de um modo geral de outros setores produtivos, inclusive os dos gêneros básicos da alimentação. O segundo foi o aumento da dívida pública. Muitas vezes, para administrá-la, emitia-se moeda, o que, normalmente, ao aumentar a circulação de dinheiro sem lastro no crescimento da economia, pressionou a subida dos preços no mercado interno. Desse modo, houve substancial elevação do custo de vida, penalizando duramente a população de baixa renda. Para se ter uma ideia disso, em 1914 o índice do custo de vida no Brasil era 100, saltando para 148,8 em 1919, para 236,6 em 1924 e para $261 \mathrm{em} 1929 .^{5}$

Em contrapartida, sabe-se que a exponencial imigração para o Brasil, acrescida de uma população recém egressa do contexto da escravidão e de um contingente enorme de homens de origem pobre, oriundo do mesmo contexto (os livres-pobres), proporcionou uma oferta gigantesca de trabalhadores, o que ajudou a inibir a elevação dos salários. ${ }^{6}$

Com efeito, a pobreza era engendrada estruturalmente. Sem direitos políticos (pois o analfabetismo funcionava como cláusula de barreira constitucional para a participação política), com direitos sociais limitadíssimos (para

\footnotetext{
${ }^{5}$ Essa síntese elaborada grosso modo foi elaborada a partir de FERREIRA, Jorge e ALMEIDA, Lucíola de Delgado (orgs.). O Brasil republicano: o tempo do liberalismo excludente. Vol. 1, Rio de Janeiro, Civilização Brasileira, 2003; FURTADO, Celso. Formação econômica do Brasil. 27 ed., São Paulo, Cia Nacional/Publifolha, 2000; PRADO Jr., Caio. História econômica do Brasil. 42 ed., São Paulo, Brasiliense, 1995 e SAMIR, Almir. Desenvolvimento desigual: ensaio sobre as formações sociais do capitalismo periférico. São Paulo, Forense Universitária, 1976. Os dados sobre custo de acima apresentados foram produzidos por Roberto Simonsen e reproduzidos por FAUSTO, Boris. A revolução de 1930: história e historiografia. 2 ed., São Paulo, Brasiliense, 1972, p. 94.

${ }^{6}$ Os livres-pobres (isto é, aqueles que, não tendo escravos, precisavam trabalhar para manter sua subsistência) foram estudados por FRANCO, Maria Sylvia de Carvalho. Homens livres na ordem escravocrata. 4 ed., São Paulo, Unesp, 1997. Sobre a situação dos trabalhadores livres no Brasil da época, duas obras, entre outras, são bastante esclarecedoras. KOWARICK, Lúcio. Trabalho e vadiagem: a origem do trabalho livre no Brasil. 2 ed., Rio de Janeiro, Paz e Terra, 1994, p. 65. PINTO, Maria Inez Machado Borges. Cotidiano e sobrevivência: a vida do trabalhador pobre na cidade de São Paulo. São Paulo, Edusp, 1994, p. 42.
} 
ser ter uma ideia, saúde e educação ainda não eram obrigações constitucionais do Estado brasileiro) e sem direito trabalhista (um candidato à presidência da República chegou a afirmar que questão operária era caso de polícia), ${ }^{7}$ a população pobre imersa naquela estrutura econômica vivia no limite da subsistência e não raro gemia sob o peso da miséria.

As pesquisas dedicadas direta ou indiretamente ao tema deste estudo são unânimes em relação a isso. Todas elas mostram como a vida era muito difícil para a maioria das famílias pobres na época da Primeira República. Uma delas, focada no trabalhador pobre na cidade de São Paulo, revela que os salários eram baixos e mal davam para cobrir as despesas elementares com moradia e alimentação. Além disso, revela também que os empregos fixos eram precários, instáveis e escassos, obrigando grande parte da população a buscar frequentemente alternativas em ocupações temporárias, itinerantes e, na maior parte das vezes, com remuneração muito baixa, o que colocava os indivíduos submetidos a essa situação na desconfortável fronteira da pobreza com a miséria. ${ }^{8}$

Dessa maneira, as famílias pobres viviam em moradias muito precárias, como Aloísio de Azevedo ilustrou em seu romance $O$ cortiço publicado em 1890. Sem alternativa, elas acabaram parando nesse e em outros tipos de habitação popular considerados pelas autoridades sanitárias insalubres e difusores de doenças contagiosas, razão pela qual foram alvos de políticas autoritárias dos poderes públicos, como as demolições em massa promovidas pelos prefeitos Barata Ribeiro e Pereira Passos na capital do país nas décadas iniciais da República. ${ }^{9}$

A dramaticidade da pobreza no Brasil durante a Primeira República pode ser observada de diversas maneiras. Uma delas é pelos requerimentos (um instrumento de ação política) da população ao agente executivo municipal e à Câmara. $\mathrm{O}$ cidadão enviava um texto às autoridades do legislativo ou do executivo do município com alguma demanda. No caso dos pobres, era

\footnotetext{
${ }^{7}$ Essas informações foram obtidas em CARVALHO, José Murilo de. Cidadania no Brasil. Rio de Janeiro, Civilização Brasileira, 2001, p. 83 e 110.

${ }^{8}$ PINTO, Maria Inez Machado Borges. Op cit. cap. 2. Além desta pesquisa, há outros estudos que mostram o mesmo. VISCARDI, Cláudia Maria Ribeiro. Op cit. CHALHOUB, Sidney. Trabalho, lar e botequim. 2 ed., Campinas, Unicamp, 2008. PATTO, Maria Helena Souza. Estado, ciência e política na Primeira República. Estudos avançados, USP, vol 13, n. 35, 1999. RAGO, Margareth. Do cabaré ao lar. 3 ed., Rio de Janeiro, Paz e Terra, 1997. DECCA, Maria Auxiliadora Guzzo. A vida fora das fábricas: cotidiano operário em São Paulo (1920-1934). Rio de Janeiro, Paz e Terra, 1987.

${ }^{9}$ Sobre a caça aos cortiços e moradias populares a obra de CHALHOUB, Sidney. Cidade febril. 2 ed., São Paulo, Cia das Letras, 1999, é uma das melhores referências.
} 
demandado geralmente ajuda para enfrentar as calamidades da vida cotidiana de uma época em que não havia política pública social.

A relação entre cidadãos pobres e os poderes públicos municipais, por meio dos requerimentos ao agente executivo e à Câmara, pode ser observada onde, raramente, tal documentação está conservada e encontra-se organizada e aberta à consulta, como em Alfenas. Situado no sul de MG, este município foi formado no contexto das oportunidades abertas pela reorientação econômica mineira ocorrida na segunda metade do século XVIII. Seus primeiros colonizadores foram proprietários rurais que buscavam terras para o cultivo de alimentos para subsistência e para os mercados vicinais de uma região então em expansão. A transformação da capital do país em sede da corte portuguesa, inicialmente, e o crescimento da cafeicultura no oeste paulista, posteriormente, ampliaram os horizontes econômicos da elite local..$^{10}$ Desse modo, aos poucos, o antigo arraial reuniu condições para torna-se município (1860) e, já na Primeira República, era dotado de um núcleo urbano, onde diversos ícones da modernidade estavam presentes (cinema, teatro, luz elétrica, posto de gasolina, fábricas e até uma escola de formação superior; a Escola de Farmácia e Odontologia de Alfenas, criada em 1914, que acabou sendo transformada em universidade federal em 2005).

E foi para estimular o fomento dessa modernização, com destaque para a reforma urbana, que grande parte dos gastos do município, advinda dos impostos pagos principalmente pelos setores ligados à cadeia produtiva agropastoril, esteve orientada durante a Primeira República, o que dificultava os cofres públicos atenderem outras demandas da população, sobretudo a sua parte mais pobre.

Mas, como se sabe, a outra face da riqueza é a pobreza. Doravante, serão os indivíduos por ela estigmatizados que nos falarão sobre seus problemas, suas angústias e temores na luta pela subsistência, por meio dos seus requerimentos feitos ao agente executivo municipal e à Câmara, para enfrentar as suas dificuldades cotidianas. Vale lembrar que, para os requerimentos serem deferidos, o agente executivo municipal e os vereadores formavam comissão para investigar se os motivos alegados pelos requerentes eram verdadeiros. Em acréscimo a isso, em anexo a estes documentos, os seus autores deveriam

\footnotetext{
${ }^{10}$ Sobre a formação econômica do município de Alfenas, pode-se consultar, entre outros, LENHARO, Alcir. As tropas da moderação o abastecimento da corte na formação política do Brasil, 1808-1842. São Paulo, Símbolo, 1979, e SAES, Alexandre Macchione et al. O sul de Minas em transição: a formação do capitalismo na passagem para o século 20. Bauru, Edusc, 2012. Quem tiver o interesse de estudar este e outros assuntos da história local pode usar como guia o catálogo, organizado por EUGÊNIO, Alisson. Fontes para o estudo da história de Alfenas. Alfenas, Universidade Federal de Alfenas, 2013.
} 
apresentar cidadãos de boa reputação, que atestassem, como uma espécie de fiador moral, a veracidade da justificativa usada para o que estava sendo requerido.

Para ouvi-los, além de ter em mente a estrutura econômica, política e social (esboçada anteriormente) na qual estavam imersos, é necessário também compreender que tal estrutura se revela no cotidiano, pois nele a história se expressa ao ser produzida, vivenciada e experimentada. Em outros termos, a cotidianidade acaba sendo um recorte que permite observar, partindo de vivências individuais ou de casos particulares, entre outros aspectos da experiência humana, as contradições de sociedades marcadas pelas desigualdades sociais. Portanto, em meio às atitudes e situações corriqueiras e repetitivas que marcam a rotina do dia a dia, neste estudo serão observados os efeitos estruturais de uma época histórica na vida cotidiana. Pois, esta encontra-se "no centro do acontecer histórico", tornando-se dessa maneira "a verdadeira essência da substância social, pois "as grandes ações não cotidianas contadas nos livros de história partem da vida cotidiana e a ela retornam", e o seu caráter histórico somente assim pode ser considerado "graças ao seu posterior efeito na cotidianidade". Enfim, acontecimentos cotidianos podem ser estudados como expressão dos aspectos estruturais da vida social, e é dessa maneira que os conteúdos dos requerimentos dos cidadãos pobres de Alfenas serão analisados como indicadores de demandas sociais de uma sociedade marcada por alta concentração de renda e por um Estado, fundamentado nos princípios do liberalismo, que negligenciou a assistência social em sua agenda de obrigações públicas, ao deixar a população afetada pela pobreza entregue à sua própria sorte. ${ }^{11}$

A Câmara Municipal de Alfenas editou uma lei em 28 de Julho de 1922 definindo no seu segundo artigo o seguinte: "São reconhecidamente pobres os chefes de família numerosa que vivem de salário, os enfermos de moléstia crônica e as viúvas que não tenham prédio senão de valor ínfimo para sua habitação."12 Alguns fragmentos de histórias dos indivíduos que foram assim reconhecidos pelas comissões de verificação de atestado de pobreza serão apresentados para conhecermos suas dificuldades, suas tragédias e suas esperanças.

Comecemos com os fragmentos de história dos cidadãos que alegavam receber salários baixos e chefiar famílias numerosas. No dia 26 de abril de 1909,

${ }^{11}$ HELLER, Agnes. 0 cotidiano e a história. 2 ed., Rio de Janeiro, Paz e Terra, 1985, p. 20.

${ }^{12}$ CMA (Câmara Municipal de Alfenas) 18.1, Lei 286, 28 de Julho de 1922, p. 156 -157. 
um cidadão, cujo nome não foi possível identificar, requereu da Câmara a remissão de impostos prediais atrasados, argumentando que "o pagamento não foi feito por não dispor de quaisquer recursos, pois como é público, é homem muito pobre e carregado de família." A comissão de finanças, encarregada de analisar a situação do solicitante, indeferiu o pedido, pois a solicitação havia sido feita somente após execução judiciária, cujos custos também deveriam ser pagos junto com os 100 mil reis de impostos atrasados. Melhor sorte teve João Francisco. Em 20 de janeiro de 1911, este negociante de quitandas no distrito de São Sebastião do Areado, pediu "como uma esmola, devido ao seu estado de completa indigência e enfermidade, que o priva de trabalhar em outra profissão, que se lhe dê baixa no lançamento dos impostos, para assim poder manter-se e adquirir os meios parcos de subsistência para si e sua família." Além disso, ainda justificou seu pedido dizendo que "não pode mendigar devido ao seu estado de saúde, que o priva de andar, e à sua avançada idade de 80 anos." ${ }^{13}$

Os dois primeiros casos são de pessoas com impostos atrasados. 0 primeiro deles predial (quase nunca eram perdoados) e o segundo de indústria e profissões (tributo devido por todo estabelecimento agrícola, industrial e comercial, bem como por todos os indivíduos que exerciam profissões autônomas). Na documentação consultada, dos 1256 requerimentos 672 foram protocolados com o objetivo de remissão, cancelamento e renegociação de dívida com o fisco municipal.

Esse também foi o caso de Olímpia Gonçalves. No dia 22 de outubro de1929, ela argumenta

\begin{abstract}
que tendo falecido seu marido Alberto Lopes Gonçalves em débito para com o município, na importância de $200 \$ 000$, de imposto de negociante de gêneros, $75 \$ 000$ referente ao exercício de 1918 e $125 \$ 000$ referente ao de 1921 , e mais multa de $84 \$ 000$, é-lhe de todo impossível se desobrigar dessa dívida para com o erário municipal, não obstante o seu melhor empenho. É tal o seu estado de pobreza e tão pesados os encargos de criação e educação dos filhos que lhe ficaram, que não pode desviar qualquer quantia do seu salário, sem ir até ao sacrifício do pão da família. Por isso, vem fazer um apelo a esse egrégio corpo legislativo para perdoar aquela dívida de seu marido, mandando cancelá-la do rol da dívida ativa. ${ }^{14}$
\end{abstract}

\footnotetext{
${ }^{13}$ PMA (Prefeitura Municipal de Alfenas) 34.1, Requerimentos 1909-1924 (a documentação não está paginada, pois é constituída de folhas avulsas reunidas em uma pasta. 0 mesmo ocorre com as demais pastas que reúnem o mesmo tipo de documentos).

${ }^{14}$ PMA 34.4, Requerimentos 1928-1929.
} 
Em diversas ocasiões os requerentes não se enquadravam na definição de pobreza firmada pela Câmara anteriormente apresentada. Mas os imprevistos, sobretudo os de saúde, os colocavam em situação, ao menos temporária, de fragilidade financeira e empobrecimento, como Simplício José Vieira que no dia 1 de fevereiro de 1909 solicitou revisão da cobrança do pagamento do imposto de Engenho dos exercícios de 1908 e 1909, argumentando que

por quanto esse Engenho é assentado em base de mal construção, que somente tem feito para pagar suas despesas menores da casa, como prova o atestado incluso, e tão bem ao conhecimento de Vossa Excelência que deixou de fazer suas reclamações em tempo próprio, devido sempre estar sofrendo incômodo de saúde, e que muito desejava que o Engenho produzisse resultado que correspondesse aos impostos. Confiando no critério de Vossa Excelência, o abaixo assinado espera merecer toda atenção neta justa reclamação. ${ }^{15}$

Era muito comum os imprevistos produzirem efeito empobrecedor coletivo, como as intempéries climáticas, o que levava uma categoria inteira de contribuintes a reivindicar perdão, ou ao menos redução, de imposto. Foi o que aconteceu em 20 de janeiro de 1919, quando vinte moradores da cidade, todos lançados no orçamento da receita da Câmara no imposto de carro de boi, reclamaram contra

o acréscimo feito pela lei municipal recentemente posta em execução e que aumenta mais dez mil reis e passou pela dita lei a ser trinta mil réis. Os reclamantes ponderam a essa Câmara que o aumento acima referido veio em época por demais inoportuna, como procuram em seguida demonstrar. As geadas do ano findo, se não extinguiram, ao menos diminuíram sensivelmente a produção de café desta zona, e aquele produto é o elemento principal de vida dos carretos. Acresce ainda que a peste afitosa quase destroçou as boiadas, agravando a situação geral dos reclamantes e a importação do comércio local tem diminuído extraordinariamente, o que produz enorme decréscimo de serviços. ${ }^{16}$

Neste caso, que ficou de ser apreciado na ocasião da cobrança do imposto, conforme resposta da comissão de finanças da Câmara, trata-se de uma situação sazonal criada por uma dependência estrutural da economia cafeeira. Quando não era por causa da geada, a colheita nos cafezais sofria grande queda provocada por ataques de insetos, como ocorreu em 1924. Neste ano, havia irrompido em Campinas uma praga cafeeira: o coleóptero denominado

\footnotetext{
${ }^{15}$ PMA 34.1, Requerimentos 1909-1924.

${ }^{16}$ CMA 34, Avulsos, 1892-1919 (a documentação não está paginada, pois é constituída de folhas avulsas reunidas em uma pasta).
} 
Stephacioderes Caffeae, que danifica por completo o fruto do café. Essa praga estava marchando de São Paulo para Minas, alarmando os envolvidos na cadeia de produção de café, pois uma afetação maior poderia provocar enorme penúria no município. Por isso, muitos cidadãos, que não se enquadravam nos critérios de pobreza definidos pelos vereadores locais, se sentiam ameaçados por ela e, consequentemente, demandaram a diminuição do valor dos impostos de indústria e profissão a serem pagos, ou até mesmo cancelá-los, como tentaram fazer os carreiros cujo requerimento foi anteriormente citado.

Muitas vezes, durante a Primeira República, cidadãos empobrecidos por não poderem mais exercer suas profissões, na impossibilidade de se aposentarem (já que não havia previdência social nessa época) buscavam alternativas para garantir a sua sobrevivência. Tal é o caso de Egídio Gomes. No dia 15 de janeiro do ano de 1911, ele assinou o seguinte requerimento:

Excelentíssimo Presidente e demais membros da Câmara de Alfenas. Eu abaixoassinado, residente neste Distrito de São Sebastião do Areado, velho e bastante alquebrado pelos anos e moléstias de que sofro ainda, não me podendo valer de minha profissão de alfaiate para poder subsistir, abri então uma taverninha com auxílio de alguns amigos e cidadãos que de mim tiveram pena, visto meu estado de pobreza, como posso prová-lo, com as atas abaixo-assinadas. Ora, assim sendo, venho por meio deste solicitar, dessa ilustrada Câmara, esmola da licença para continuar com a dita taverninha durante o corrente ano tão somente.

Em resposta, a comissão de finanças, embora reconhecesse "que o peticionário é merecedor do favor que pede, mas (...) não podendo abrir um precedente que lhe disseminará [outros casos] no futuro, é de parecer que o peticionário não seja atendido" ${ }^{17} \mathrm{O}$ receio da vereança local era o de que outros estabelecimentos semelhantes fossem abertos clandestinamente, sem a devida autorização prévia, como a taverna mencionada no requerimento anterior.

Era comum que indivíduos pobres, como o ex-alfaiate acima identificado, buscassem alternativas para fazer frente às calamidades da vida. No caso dele foi feita a opção por trocar a atividade profissional. Outros preferiam ampliar a renda com trabalhos complementares e, ao fazerem isso, às vezes eram alvos do fisco municipal. Em 20 de janeiro de 1916, José Monteiro Vitória alegou ter sido lançado na lista de contribuintes do imposto de indústria e profissões como proprietário de padaria. Para escapar da cobrança, argumentou que "não exerce essa indústria como negócio, pois de sua casa são

${ }^{17}$ PMA 34.1, Requerimentos 1909-1924. 
vendidos biscoitos e alguns pães," resultantes do "trabalho de sua senhora, em horas que lhe permitem os múltiplus afazeres domésticos, como, aliás, acontece com quase todas as casas de famílias pobres que procuram auxiliar o seu chefe em seus pesados deveres," e por isso "requer a Vossas Excelências mandar cancelar tal lançamento por ser de inteira justiça. ${ }^{18}$

Não foi possível saber a resposta da Câmara Municipal. Todavia, seu argumento, de que "quase todas as casas de famílias pobres que procuram auxiliar o seu chefe em seus pesados deveres," faziam o mesmo, revela o quanto era comum à população afetada pelas mazelas sociais acumular outras atividades em busca da complementação da renda necessária à subsistência. Neste caso, fazer bolos, biscoitos, pães, ou mesmo quitandas, para oferecer ao público de porta em porta era uma das mais comuns formas de obtenção de recursos para fazer face às despesas básicas nos centros urbanos do Brasil desde a época colonial. Isso mostra que, por parte de muitos indivíduos, não havia acomodação à pobreza.

Assim, no dia 19 de janeiro de 1912, Emília Bernardina de Jesus afirmou que

na impossibilidade de outros meios de se manter na sua velhice, dedicou-se a fazer quitandas e, quase somente para vendê-las, abriu, há tempos, uma vendinha que foi logo obrigada a fechar, por falta de fundos e prejuízos que lhe acarretava. Ora, ficando restando à fazenda municipal o imposto do último ano, por falta absoluta de recursos, e tendo-se, de então até hoje, agravado ainda mais sua situação, acha-se atualmente no caso de perder o teto que lhe abriga, se não vos apiedardes de tão crítico estado. Nessa circunstância, a suplicante humilde e confiada nos elevados sentimentos de humanidade que tanto enobrecem essa ilustre Assembléia, vem pedir-vos, por equidade, o cancelamento de respectivo lançamento. ${ }^{19}$

Para sua sorte, seu pedido foi deferido. o procedimento acima exposto também era feito por pessoas não tão pobres, mas que lutava com certa dificuldade para viver. Antônio Silva, no dia 28 de fevereiro de1920, reclamou o seguinte:

Tendo sido lançado pela coletoria municipal, como contribuinte da indústria e profissão, sob a tábula de $100 \$ 000$, que atinge a profissão de retratista ou fotógrafo, tenho a fazer as seguintes considerações que me parecem justas. A minha profissão, desde que aqui cheguei há quase quatro anos, foi sempre a de professor de ensino secundário, ministrando lições de português, desenho e pintura, não só no Instituto Técnico, como em domicílios a alunos particulares,

\footnotetext{
${ }^{18}$ CMA 34, Avulsos, 1892-1919, sem paginação.
}

${ }^{19}$ PMA 34.1, Requerimentos 1909-1924. 
o que é facilmente demonstrável. E, como em nosso País, mau grado o descaso com que os governos desamparam a arte e as letras não oficializadas, o professor não passa de um operário vulgar muito sacrificado no seu mister, entendi que, numa ou noutra hora que, às vezes me ficam disponíveis, além de quase todas as outras em que emprego de fato a minha atividade profissional, poderia, sem incomodar a procuradoria da Câmara, executar um ou outro quadro de reprodução de retrato, como tenho feito em Belo Horizonte, Ouro Preto, Barretos, Bebedouro e muitos outros lugares por onde tenho vivido trabalhando nas mesmas, condições que aqui, sem que entretanto nenhuma das Câmaras daqueles lugares me onerassem taxando qualquer imposto. É que logo compreenderam que estes poucos trabalhos que executo nesta arte não são mais que uma consequência muito natural e lícita, simples, amparo à mesma atividade profissional, que, por si só, não me seria suficiente para fazer face às despesas a que o viver me submete. ${ }^{20}$

A Câmara acabou mudando a classificação do requerente no imposto de indústria e profissão de retratista para pintor, o que reduziu um pouco o valor do imposto a ser pago. No caso dele, na condição de professor do antigo secundário (correspondente ao ensino médio atual) que, nos seus próprios termos, não passava "de um operário vulgar muito sacrificado no seu mister" (isso foi dito em 1920, mas parece tão atual), a luta contra o empobrecimento foi acumular a atividade de pintor. Pois, era muito comum as pessoas ricas encomendarem obras de pintores para decoração de suas residências, principalmente no tempo da euforia que marcou as elites econômicas da Belle Époque, as quais, ávidas por afirmação social, buscavam se adequar aos refinamentos culturais europeus.

Havia casos muito piores. Muitos indivíduos afirmavam estar em situação de miséria. No dia 12 de novembro de 1920, o escrivão que por dona Anna Victória do Nascimento assinou seu requerimento, por esta não saber escrever, diz que ela, "desejando edificar uma casinha nesta cidade, para abrigar a seus filhinhos, e sendo viúva paupérrima, vem muito respeitosamente requerer", ao agente executivo municipal, "uma posse devoluta, nos confins da rua Guanabara do lado norte, prontificando-se a pagar os devidos emolumentos, levando em conta suas condições financeiras." Para felicidade dela, seu pedido foi deferido. A mesma sensação pôde ser experimentada por Eufrasino José Alves. Identificando-se como "homem doente, sem poder trabalhar, vivendo da caridade pública," resolveu "apelar aos nobres sentimentos de caridade" da Câmara, "afim de ser excluído o seu nome como contribuinte do imposto predial, referente à sua casinha em ruínas, coberta

${ }^{20}$ PMA 34.2, Requerimentos 1920-1921. 
de capim, situada neste distrito, assim como aliviá-lo dos impostos devidos dos exercícios de 1917 a 1920." Outra pessoa contemplada com o deferimento de seu pedido foi Francisca Uberlina da Conceição. Seu caso parece ser o mais dramático de todos. No seu requerimento ela diz o seguinte:

Depois do longo período de vinte anos entregues aos cuidados que dispensou ao seu esposo João Candido, mendigo cego, residente nessa cidade, vê-se, atualmente, afligida pela mesma moléstia de seu companheiro e, não possuindo o menor recurso para suas subsistências, vivem da caridade pública. Para aliviar o triste destino que lhes foi cruel, vem pedir a essa edilidade a importância necessária para as despesas de viagem a São Paulo, onde espera bom êxito em uma intervenção médica a que vai se submeter. Certa do espírito de caridade dos dignos dirigentes deste Município rende graças aos céus com seus agradecimentos, por haver recebido esse auxílio que lhes virá trazer melhores dias. Seja Deus o confidente desse seu pedido. ${ }^{21}$

Tal requerimento é de arrancar lágrimas, lágrimas de sangue, dos leitores mais sensíveis. A Câmara, sensibilizada com essa história trágica, (escrita pelo escrivão que a rogo elaborou a solicitação, porque a solicitante estava impedida de escrever por causa da sua cegueira) acabou aprovando a liberação de uma quantia de 80 mil réis para atender à demanda da requerente.

Afora esses casos comoventes, havia as solicitações de trabalhadores que procuravam ajuda das autoridades do executivo e do legislativo municipais, para seus filhos terem uma vida melhor no futuro pela via da educação. Vários são os requerimentos com esse conteúdo. Um deles, assinado no dia 28 de março de 1924 por Victor Tamburini, chama atenção por se tratar de um italiano que, depois de ter conseguido formar sua filha no secundário, a qual conseguiu passar no exame de admissão da Escola de Farmácia e Odontologia de Alfenas (na época uma entidade particular), solicitou ao agente executivo municipal

mandar admitir por conta do Município, um dos lugares que vem de vagar-se na Escola de Farmácia e Odontologia desta cidade, a sua filha Carmem Tamburini, que se acha habilitada para matricular-se no curso odontológico. Operário que é, com rendas limitadas e muitos outros filhos que reclamam educação, não tem outro remédio senão recorrer à generosidade do pode público municipal, ainda uma vez, que certo não deixará de atendê-lo, sabido o pendor do seu chefe supremo para causas do Ensino, e o seu espírito de justiça sempre pronto a atender os rogos, dos que se vêm dedicando à grandeza desta ilustre terra que adotou como pátria e berço de seus filhos. ${ }^{22}$

\footnotetext{
${ }^{21}$ PMA 34.3, Requerimentos 1924-1926.
}

${ }^{22}$ PMA 34.3, Requerimentos 1924-1926. 
Não foi possível localizar a resposta do chefe do executivo local. Mas o nome da sua filha, bem como de mais um filho e outra filha, consta da relação de matrícula da referida faculdade. O caso daquele operário trata-se de uma estratégia para superar estruturalmente a pobreza e revela possibilidades pequenas, mas reais, de tentativa de promover a ascensão social por meio da educação, em uma época de poucas oportunidades de admissão em escolas de formação superior, principalmente para as famílias com prole numerosa e chefe com remuneração limitada.

A propósito, a reduzida oferta de ensino (já que a Constituição não apresentava a educação como direito) e o seu efeito mais perverso, principalmente na área rural, o analfabetismo, é outro mecanismo de engendramento estrutural da pobreza. Grande parte da população brasileira estava afetada por este mal. Tanto que o partido da mocidade, com sede em São Paulo, em uma carta enviada em 25 de setembro de1926, ao solicitar às câmaras municipais do país maior empenho financeiro em prol da educação, sugerindo gasto mínimo de 20 \% da receita dos municípios com educação, afirma: "Somos um dos países mais flagelados pelo analfabetismo e que daí advém a maior parte dos males de que sofre o Brasil." ${ }^{23}$ É por esse motivo o fato de muitos dos cidadãos pobres de Alfenas não terem assinado seus requerimentos.

A pobreza sob a qual grande parte das famílias brasileiras murmurava agonicamente seus sofrimentos parece ter recrudescido nos idos de 1924 . 0 país não ia bem. A eleição de Arthur Bernardes para o governo federal gerou desgaste no pacto oligárquico, ampliando as tensões políticas de uma sociedade já bastante tensa politicamente desde o final da época imperial. Em meio a isso, cresciam os movimentos políticos, sobretudo das classes médias, motivados pela crise financeira que assolava o país (devido à superprodução de café e o acúmulo de dívidas para financiar os seus excedentes cada vez maiores). O mais grave desses movimentos, as revoltas tenentistas, iniciadas em 1922, culminou na Coluna Prestes (cujo objetivo era semear a revolução pela nação), criou um clima de grande tensão nacional. Para se ter uma ideia disso, grande parte da impressa publicava artigos, verdadeiros panfletos, para inflamar a população esclarecida.

O Jornal de Viçosa, por exemplo, no dia 26 de Julho de 1924, publicou em seu editorial um texto intitulado "Alto lá canalhas!", referindo-se aos revoltosos, no qual diz : "É o grito de dor e revolta (...) contra o crime nefando, contra o ato de selvagem fratricídio praticado por meia dúzia de cafajestes que se dizem

${ }^{23}$ PMA 34.3, Requerimentos 1924-1926. 
oficiais do exército e que, pretendendo ferir de morte a República quiseram golpeá-la no coração (...). Alto lá canalhas!, exclama a alma nacional" ${ }^{24} \mathrm{E}$ seguiu detratando o movimento tenentista, conclamando o povo a comparecer aos comícios, que salpicavam as cidades, e a formar batalhões patrióticos, como em Viçosa (terra do então presidente do Brasil).

Os ânimos estavam exaltados. E para incendiar ainda mais o país, as contas públicas haviam estourado. No dia 27 de fevereiro de 1925, o general Isidoro Dias Lopes, considerado moderado, enviou uma carta ao deputado federal Azevedo Lima, fazendo o seguinte comentário a esse respeito: "Fantasticamente rico, o Brasil, sob o ponto de vista financeiro, está falido. Não pode pagar os fabulosos juros da sua fabulosa dívida, apesar dos milhões de contos de réis extorquidos do povo nestes últimos 20 anos." A política de valorização artificial do café, pela compra dos seus excedentes com financiamento estrangeiro, havia ido longe demais. A emissão de moeda para rolá-la pressionou a inflação. Consequentemente, o custo de vida durante o governo Bernardes saltou de 184, quando ele assumiu a presidência em 1922, para 260 no final do seu mandato. A situação estava dramática. Incentivados pela garantia de preço do principal produto de exportação brasileiro, muitos agricultores passaram a investir na cafeicultura, produzindo alimentos básicos apenas para consumo próprio. Começou a faltar comida, apesar do Decreto presidencial n. 16.419, editado em 19 de março de 1924, ter ameaçado desapropriar terras para a produção de alimentos. Por esse motivo, aquele general, na mesma carta, comentou: "O operariado e uns 30 milhões de espoliados, sem dinheiro de ordem alguma, estão quase na miséria, por uma artificial e criminosa carestia de vida". ${ }^{25}$

Enquanto isso, em Alfenas, a pobreza aumentava seu séquito de agonizantes. Indicador disso é o requerimento de uma entidade beneficente local, que, ao solicitar aumento do valor da verba repassada pelos cofres municipais para ela atender aos necessitados do município, no dia 22 de abril de1924 dá o seguinte testemunho:

A Conferência de São Vicente de Paulo, benemérita associação de caridade, que nesta cidade tem prestado relevantes serviços no socorro aos pobres mendigantes e manutenção dos seus pobres lares, sem que perambulem pelas ruas, estando de porta em porta, diante da tremenda crise de carestia de vida, que duplicou o custo de vida de tudo e principalmente dos víveres

\footnotetext{
${ }^{24}$ Jornal de Viçosa, ano 2, n. 2, 26/07/1924, p. 1.

${ }^{25}$ Os comentários do general Isidoro, os dados sobre o custo de vida e a informação sobre o referido decreto foram obtidos em FAUSTO, Boris. Op cit, nas p. 94 e 95.
} 
de primeira necessidade, faltando-lhes os preciosos recursos, se tornando precária e insuficiente a importância mensalmente coletada, existindo já em sua tesouraria um déficit avultado e com tendência de aumento, sentiu-se a Conferência na emergência de deixar que, de novo, assistíssemos o espetáculo triste e desolador do esmolar contínuo pelas ruas, de infelizes criaturas doentes e andrajosas, e por isso organizou uma comissão infra-assinada para conseguir pelos meios que julgar conveniente o necessário para a cobertura do déficit e a continuação de obra tão meritória, como a de socorrer os infelizes mendigos de Alfenas. A comissão que vem encontrando do culto povo desta terra o mais confortador apoio no apelo que lhe dirigiu, em sua última reunião, resolveu pedir a essa ilustre edilidade um auxílio para o fim acima descrito, que é o de prestar assistência aos nossos conterrâneos, na sua maioria inválidos e faltos de recursos, na contingência dolorosa de verem desaparecer o pão levado cotidianamente pelas caridosas mãos dos abnegados Vicentinos de nossa terra. Justo é também que a ilustre edilidade regente, com o tanto critério e brilho dos destinos do culto povo de Alfenas e pronta sempre a elevá-lo no conceito de filantropo e culto, atenda o que se lhe pede. ${ }^{26}$

O pedido foi deferido imediatamente. Um dia após ter sido feito, foi decidido que fosse entregue aos vicentinos o valor de 1:500\$00 (um conto e quinhentos mil reis).

Pelo que se percebe, a situação estava na beira da catástrofe. No mercado alfenense, tal como na maior parte do país, os preços dos alimentos estavam pela hora da morte. Tanto que um morador da freguesia de São Joaquim da Serra Negra, no dia18 de outubro de 1924, enviou ao poder legislativo local um protesto bastante esclarecedor a respeito do que se passava no município:

Excelentíssimo Senhor Presidente e demais membros da Câmara Municipal de Alfenas. Eduardo Daniel Ferreira Dias, professor, brasileiro, residente nesta Freguesia, por si e como representante da população pobre da sede, vem à presença da ilustrada Câmara protestar contra a enorme exportação de suínos e cereais para outros municípios circunvizinhos, deixando esse abuso formidável os habitantes de São Joaquim sem recursos e alimentos. A comprovação deste fato está no elevado preço aqui atingido os gêneros de primeira necessidade: a saca de arroz de 58 quilos a $90 \$ 00$ e $100 \$ 000$, feijão a $55 \$ 000$ e $60 \$ 000$ o alqueire de 40 litros (mal medido), toucinho a $38 \$ 000$ a arroba e, ainda a ser encontrado à venda, ao passo que, diariamente, seguem para a Estação grandes partidas em prejuízo do povo. O comércio é livre, mas tem seus limites na proibição de certos abusos, como este. Por que em zonas menos produtivas, como Barro Preto, encontram-se gêneros pela metade ou terça parte do preço? Espera o suplicante que a Câmara não deixará de tomar providências, à semelhança do Rio, São Paulo, Bahia, Pernambuco, Belo Horizonte, etc., crescendo impostos

${ }^{26}$ PMA 34.1, Requerimentos 1909-1924. 
pesados àqueles que na ganância de grandes lucros não se incomodam com a fome e a miséria do povo. ${ }^{27}$

Em contrapartida, os salários das famílias pobres, normalmente baixos, já não davam conta de cobrir nem as despesas mais elementares. Por essa razão, muitos funcionários municipais pediram aumento. Um deles, Cristiano de Almeida Vieira, no dia 20 de outubro de 1924, elaborou o requerimento abaixo reproduzido destinado ao agente executivo municipal e à Câmara de Alfenas:

O condutor de mulas de Gaspar Lopes a esta cidade e virce-versa, percebendo pelo seu trabalho apenas a quantia de $100 \$ 000$ (cem mil reis) mensais, vem muito respeitosamente requerer a Vossas Excelências uma gratificação mensal de $100 \$ 000$ (cem mil reis), afim de que possa se manter no cargo na atual crise que atravessamos, com o custo de um litro de feijão a $2 \$ 000$, idem o arroz, e tudo o mais aí assim. Apelando para o critério altamente humanitário dessa edilidade que sempre tem presidido seus atos, subvencionando ou gratificando a outros funcionários, espera ser-lhe feita a acostumada justiça.

O seu pedido foi indeferido sob a alegação de que faltava verba para tanto. Outros funcionários tiveram a mesma atitude. No mesmo dia, alguns deles resolveram se unir para solicitar da Câmara melhoria salarial com o seguinte argumento:

Os infra-assinados, administrador e demais empregados do matadouro municipal, vêm apelar para o alto critério dessa edilidade, solicitando-lhe aumento de ordenado, pois que, em virtude da grande alta nos gêneros de primeira necessidade, o atual não lhes permite fazer as despesas necessárias ao arrimo de suas famílias. Este gesto é motivado tão somente pelas dificuldades por que vêm passando. Esperam do espírito esclarecido dos seus dirigentes a sua consideração; atendendo ao pedido que ora lhes fazem, com o deferimento deste, terão cometido um ato de verdadeira justiça. ${ }^{28}$

Nesse caso a comissão de finanças ficou de estudar, no orçamento do próximo ano, a possibilidade de atender à solicitação de funcionários de um estabelecimento público fundamental para a satisfação da demanda de um dos mais importantes alimentos da diária subsistência humana; a carne.

o que as demandas das pessoas que expuseram fragmentos de suas vidas podem nos revelar além do que já foi dito? Revelam outro traço estrutural de uma sociedade extremamente desigual, expressão cotidiana das contradições da estrutura econômica, política e social do Brasil, durante a Primeira República. Pois um dos fatores que explica a motivação para elas

${ }^{27}$ PMA 34.1, Requerimentos 1909-1924.

${ }^{28}$ PMA 34.1, Requerimentos 1909-1924. 
serem expostas pelos pobres, ou pessoas momentaneamente fragilizadas economicamente, por meio de requerimentos é a cultura da dádiva. Fundada no paternalismo, ela pressupõe a capacidade de um provedor poderoso fazer concessões (normalmente materializada em ações isoladas voltadas para amparar, proteger ou socorrer, em algumas ocasiões, a população pobre) aos que a ele estão submetidos, como forma de reforçar sua posição de mando.

Segundo estudo dedicado a este assunto, a dádiva, como estratégia política de dominação, substitui os direitos básicos da cidadania. Assim, praticada de forma sistêmica, funciona como um meio de perpetuar a pobreza, transformando os indivíduos pobres em sub-cidadãos. ${ }^{29}$

Os pedidos feitos nos requerimentos investigados nesta pesquisa são, além de um dos instrumentos de ação política dos cidadãos, um exemplo da crença dos indivíduos afetados pela pobreza de serem contemplados com tal dádiva, com a ação paternal que ela implicava, do poder público municipal. Trata-se de um gesto, embora humilhante, de resistência possível, dentro de uma ordem política opressora, contra situações trágicas engendradas por uma estrutura social perversa que, neste e em outros países com características estruturais iguais ou semelhantes às nossas, ainda constituem um grande desafio a ser superado.

Portanto, as demandas requeridas pelos cidadãos pobres de Alfenas ao poder público municipal, na Primeira República, mostram que a pobreza, gerada estruturalmente por uma formação social fundamentada no "liberalismo excludente", afetava dramaticamente a vida cotidiana de muitos indivíduos, que para amenizar seus sofrimentos procuraram, por meio de requerimentos, apelar para a dádiva dos poderes públicos, o que contribuiu para reforçar a cultura paternalista da sociedade brasileira da época e para abrir o caminho da construção do Estado providencialista no país. ${ }^{30}$

Com esses argumentos, procurou-se neste artigo mostrar que os requerimentos dos cidadãos enviados aos poderes legislativo e executivo municipais são uma fonte com grande potencial para estudos no campo da história política e social e, mais do que isso, contribuir para a compreensão de uma forma até então não estudada de manifestação política de uma população,

\footnotetext{
${ }^{29} \mathrm{O}$ estudo em questão foi elaborado por SALES, Teresa. Desigualdade social e pobreza no Brasil. Revista Crítica de Ciências Sociais, n. 39, pp. 163-181, 1994.

${ }^{30} \mathrm{O}$ conceito de Estado providência ("um vasto e organizado aparelho público que ao mesmo tempo estimula a produção e corrige as desigualdades do mercado") e sua formação histórica no Brasil é analisado por BOSI, Alfredo. Dialética da colonização. São Paulo, Cia das Letras, 1995, pp. 273-307. O conceito acima apresentado encontra-se na p. 274.
} 
sobretudo a parcela mais pobre dela, diante das suas dificuldades cotidianas. Dessa maneira, espera-se que outros pesquisadores interessados na história dos municípios possam buscar essa documentação em diversas localidades e, em seguida, elaborar novas pesquisas com base nela para ajudar a desenvolver uma nova frente de trabalho que possa contribuir para promover o avanço do conhecimento historiográfico da experiência política e social brasileira durante diferentes épocas de nossa história republicana, particularmente no período aqui estudado, por se tratar de uma época na qual a sociedade brasileira estava desprovida dos direitos sociais mais elementares.

Artigo recebido para publicação em 04/01/2017

Artigo aprovado para publicação em 20/04/2017 